\title{
«Земельный вопрос» в Кубанской области и материальное положение казачества в конце XIX в.
}

\author{
Пахомов А.В. \\ Кубанский государственный технологический университет, \\ 350072, Россия, г. Краснодар, ул. Московская, 2 \\ E-mail: Pahomov_an1981@mail.ru
}

\begin{abstract}
Аннотация. Отмена крепостного права, окончание долголетней Кавказской войны и интенсивное железнодорожное строительство, соединившее Кубань с другими регионами страны, привело не только к стремительному экономическому развитию, но и к массовому переселения тысяч крестьян. Однако развитие капиталистических отношений в казачьих станицах с одной стороны превращало казачество в землевладельческих «рантье», а с другой стороны данный фактор в совокупности с казачьими повинностями приводил к социально-экономическому расколу казачьей общины. Особое внимание автор уделяет рассмотрению одного из основных факторов «земельного вопроса», который являлся основополагающим в социальном расслоении казачества. Исследование данной проблемы и изучение факторов социально-экономического расслоения кубанского казачества раскрывает основные причины участия в революционном движении начала XX в. значительной части казачества.
\end{abstract}

Ключевые слова: казачество, Кубанская область, земля, земельный пай, сословие, расслоение, переселенцы, иногородние, повинности, войсковая собственность.

Для цитирования: Пахомов А.В. 2021. «Земельный вопрос» в Кубанской области и материальное положение казачества в конце XIX в. Via in tempore. История. Политология, 48 (2): 424-434. DOI: 10.52575/2687-0967-2021-48-2-424-434.

\section{«The land issue» in the Kuban region and the financial situation of the Cossacks at the end of the XIX century}

\author{
Andrey V. Pakhomov \\ Kuban State University of Technology, \\ 2 Moskovskaya St., Krasnodar, 350072, Russia \\ E-mail: Pahomov_an1981@mail.ru
}

\begin{abstract}
The abolition of serfdom, the end of the long Caucasian War, and the intensive railway construction that connected the Kuban with other regions of the country, led not only to rapid economic development, but also to the mass resettlement of thousands of peasants. However, the development of capitalist relations in the Cossack villages, on the one hand, turned the Cossacks into land-owning «rentiers», and on the other hand, this factor, together with the Cossack duties, led to a socio-economic split of the Cossack community. The author pays special attention to the consideration of one of the main factors of the «land issue», which was fundamental in the social stratification of the Cossacks. The study of this problem and the study of the factors of socio-economic stratification of the Kuban Cossacks reveals the main reasons for the participation in the revolutionary movements of the early twentieth century. a significant part of the Cossacks.
\end{abstract}

Keywords: Cossacks, Kuban region, land, land share, estate, stratification, immigrants, nonresidents, duties, military property. 
For citation: Pakhomov A.V. 2021. «The land issue» in the Kuban region and the financial situation of the Cossacks at the end of the XIX century. Via in tempore. History and political science, 48 (2): 424-434 (in Russian). DOI: 10.52575/2687-0967-2021-48-2-424-434.

\section{Введение}

Кубанская область была образована 8 февраля 1860 г., а постановлением от 16 ноября 1860 г. Черноморское казачье войско и западные бригады Линейного казачьего войска официально были переименованы в Кубанское казачье войско [История Кубани, c. 135]. Новообразованная область вошла в число самых крупных губерний и областей европейской части России, занимая площадь 81,216,5 кв. версты [Первая всеобщая перепись..., 1897]. Однако данная территория была практически не заселена, а самостоятельная казачья колонизация новых земель не могла дать должного результата ни в промышленно-сельскохозяйственной отрасли, ни в увеличении численности населения региона. Только отмена крепостного права в 1861г. и окончание Кавказской войны в 1864 г. послужили началом масштабного переселения на Северный Кавказ.

Однако переселение в Кубанскую область как на территорию казачьего войска лиц не войскового сословия строго ограничивалось. Царское правительство, рассматривая экономическое и политическое закрепление в новой области как приоритетное, было вынуждено принять ряд постановлений, направленных на реформирование данных ограничений. Так, 10 мая 1862 г. было издано положение «О заселении западной части Кавказского хребта казаками и другими переселенцами из России», а 29 апреля 1868 г. было принято постановление «О дозволении русским подданным невойскового сословия селиться и приобретать собственность в землях казачьих войск» [Прошлое и настоящее Кубани..., с. 165]. По нему переселенцы (отставные солдаты, крестьяне и мещане) получили право приобретать в собственность любые строения без разрешения войскового начальства, однако земля оставалось в войсковой собственности, и за право пользования ей с лиц не войскового населения, т. е. «иногородних», взималась посаженная плата [Симененко, 2003, с. 75]. Таким образом, законы и положения, принятые в 1862 и 1868 гг., давали возможность проживания в области (т. е. на войсковых землях) не казачьему сословию и допускали развитие частной собственности.

В результате принятых постановлений численность населения Кубанской области к 1897 г. выросла до 1918881 чел. [Первая всеобщая перепись..., 1897]. Однако с ростом численности населения области произошло и существенное изменение в сословнонациональной структуре региона; по данным той же переписи, казачество перестало быть большинством и составляло 787197 чел. (44,7 \%), а численность иногороднего населения с 1861 по 1904 г. выросла в 237 раз (с 5243 до 1242 750) [Трехбратов, 2003, с. 282].

Таким образом, постоянная миграция, высокий естественный прирост населения, а также экономическое развитие привели к небывалому спросу на землю и, как следствие, к обострению земельного вопроса.

\section{Объекты и методы исследования}

Объектом данного исследования является изучение истории земельных отношений в Кубанской области в конце XIX в., а также социально-материальное расслоение кубанского казачества. Для наиболее объективной оценки были применены основные методы исторического исследования, такие как историко-генетический, проблемнохронологический и историко-сравнительный. В исследовании автор придерживается принципов историзма, хронологии и объективности при анализе исторических фактов и событий. Историко-генетический метод был взят за основу для изучения основных причин и выявления основных факторов возникновения и развития земельного вопроса и материального расслоения кубанского казачества. Проблемно-хронологический метод был 
взят за основу в изучении динамики изменения численности бедных казачьих хозяйств, а историко-сравнительный метод был взят за основу в изучении отечественных источников и литературы с целью выявить и дать наиболее точную оценку описываемых событий.

\section{Результаты и их обсуждение}

Благодаря климатическим условиям и обилию плодородной земли основой экономики Кубанской области являлось земледелие, а разветвленная сеть железных дорог и близость морских портов способствовали превращению региона к началу XX в. в крупного поставщика зерна. Так, если в 1873 г. под посевы распахивалось 805327 десятин земли, то в 1893 г. уже 1996640 десятин [Ладоха, 1923, с. 6]. Таким образом, земля являлась основным богатством.

Однако большая часть земельного фонда Кубанской области была законно закреплена за казачеством. Так, из 8.7 млн десятин областной земли 6799841 десятин (73,2 \%) являлась казачьей войсковой землей [Отчет начальника Кубанской области за 1901 г.] и находилась в общевойсковой собственности, тем самым являлась своеобразной платой за службу государству. Оставшийся земельный фонд $(26,8$ \%) был собственностью казны, крестьянских сельских и горских обществ, а также частных лиц [Ратушняк, 1974, с. 206].

Земельные отношения в кубанских казачьих обществах регулировались государственными нормативно-правовыми актами. Основным таким актом было «Положение о поземельном устройстве станиц и о войсковых запасных землях» от 21 апреля 1869 года [Остапенко, 2004, с. 61]. Согласно данному положению, вся войсковая земля делилась на три категории: 1) станичные (юртовые) земли, составлявшие 5228811 десятин и предназначавшиеся для наделения лиц войскового сословия (станичных казаков); 2) запасная (резервная) войсковая земля составляла 1070991 десятин и предназначавшаяся для новых казачьих поселений и растущего казачьего населения. Данная категория земли находилась в ведении местных войсковых управлений, которые могли использовать её как резерв будущих станичных наделов, а до данного момента использовать как пастбища или для другой войсковой надобности (к примеру, сдача в аренду); 3) казачья частновладельческая земля составляла полмиллиона десятин ${ }^{29}$ и возникла после окончания Кавказской войны, когда земельными наделами наделялись войсковые чины и казачьи переселенцы. Наделы казачьих офицеров представляли собой награду за заслуги и предоставлялись им вместо пенсий, однако с запретом на продажу.

Основной особенностью Положения 1869 г. было то, что «земли, отведенные станицам, состоят в общинном владении общества каждой станицы. Никакая часть земли и никакое угодие, в черте станичного юрта, заключающегося, не могут выходить из владений станичного общества в чью-либо собственность» [Остапенко, 2004, с. 62]. Таким образом, данное Положение регламентировало земельные отношения в казачьих станицах, но самое главное, запрещало продажу войсковой земли, что значительно затрудняло обогащение зажиточного казачества.

Однако для наилучшего понимания истоков зарождения казачьей земельной проблемы и, как следствие, социального расслоения среди казачества необходимо рассмотреть основные формы земледелия, применяемые в казачьих станицах. До перехода на «паевое земледелие» в станицах широко использовалось общинное землепользование, развитие которого было продиктовано военными условиями Кавказской войны. Опасность заставляла «вести общинное хозяйство, пользуясь угодьями или всей общиной или разделяя их по взаимным соглашениям на полосы и паи» [Симененко, 2003, с. 50].

Однако отрицательной стороной общинного землевладения была просуществовавшая до начала 1880-х гг. ее «вольнозахватная» форма, внесшая существенный социальный раскол в казачество. По сути, в станицах и хуторах никто не придерживался строго отве-

\footnotetext{
${ }^{29}$ ГАКК. Ф. 574. Оп. 1. Д. 3018. Л. 17-18.
} 
денных им наделов, а обрабатывал земли, кто сколько мог. Земский статистик Л.В Македонов так описывал данную форму земледелия: «У кого много худобы больше захватит, потому что может больше обрабатывать, а бедному много брать не под силу. Сильная семья, где много работников и скота, и землю пашет, и лес возит, и груши трусит, а бедному нет ничего» [Куценко, 1993, с. 79]

Несколько иную форму описания земельной ситуации дает Е. Передельский: «В толоке, равно как и за полем (за толокой), пахотная земля не делится, но каждый домохозяин знает свои загоны (пашни и нивы), и никто не имеет права вспахать чужой загон. Если же чей-либо загон по какой бы то ни было причине останется невспаханным, то он уже делается ничей, и его на следующий раз может вспахать кто вздумает, кто первый поспеет» [Прошлое и настоящее Кубани..., 1994], т. е. земля захватывалась только в случае, если оставалась не распахана.

Как правило, самовольные захваты земли провоцировались зажиточным казачеством, так как именно данная категория казачества была обеспеченна гужевой силой, наемными рабочими и сельскохозяйственным инвентарем, а не имевшие возможности обрабатывать свою землю казаки попадали практически в аграрную зависимость от более богатых соседей.

Но быстрый рост товарно-денежных отношений (связанные с растущими ценами на аренду земли), заставлял рядовое казачество требовать от станичных обществ выделения своих земельных наделов. Так, приговор казачьего схода в станице Брюховецкой, прошедший в октябре 1881 г., показал всё недовольство рядового казачества общинным земледелием: «Мы постановляли приговоры о том, чтобы богачи не запахивали «не подлежащие им земли», не имели тайных сделок с иногородними, не пользовались землей в тех местах, где обществом воспрещается, но приговоры эти не исполнялись. Поэтому группа бедняков... требует надлежащих им паев земли, чтобы раз и навсегда... распорядиться ею как хозяину, без всякого нарекания со стороны сильных» [Куценко, 1993, с. 79].

Таким образом, распределение станичных угодий и переход на паевую систему проходил не по решению войскового или станичного начальства, а по усмотрению и решению казачьих обществ на станичных и хуторских сходах (кворум должен был быть не менее 2/3 казаков) [Остапенко, 2004, с. 63]. Причем данный переход затянулся в области на несколько лет. В результате в Прикубанских станицах (Черноморье) на паи разбивалась вся земля, и пахотная, и сенокосы, а выгоны вокруг станиц оставались в общинном пользовании. Паи раздавались по жребию, т. е. каждый казак вытягивал столько раз жребий, на сколько полос была разбита станичная земля. Ввиду того, что земля в данных отделах была одинакового качества, земельные паи всей казачьей семьи выделялись одним участком.

В Закубанских станицах, где качество земли было существенно хуже, но были хорошие луга, вся станичная земля разбивалась на несколько полос под толоку, сенокос и пашни, и одна семья получала несколько участков разного качества земли. Казаки данного региона жребий тянули, как правило, не индивидуально, а группой, в основном по соседскому признаку, для дальнейшего самостоятельного распределения земли внутри группы, а также в виду существенной нехватки сельхозинвентаря для последующей совместной обработки земли. Данный тип «мини-общинного земледелия» был выгоден для рядового казачества и со временем стал практиковаться также и в Прикубанье.

Право на земельный пай предоставлялось всем казакам при достижении 17-летнего возраста. На основании правительственных распоряжений «О поземельном устройстве в казачьих войсках» от 1869 и 1891 гг. земли, отводимые казачьим обществам, «распределялись для наделения лиц войскового сословия на равные по достоинству участки, так называемые паи». Вдовы казачьих офицеров, чиновников и рядовых казаков до момента достижения сыновьями 17 лет или до выхода дочерей замуж сохраняли право на весь пай мужа, а затем оставалась только половина пая. Вдовам без детей полагалась только поло- 
вина пая. Размер земельного пая в области, согласно положению 1869 г., составлял от 16 до 30 десятин земли [Остапенко, 2004, с. 62].

Однако постоянный рост казачьего населения приводил к сокращению земельных наделов, вследствие чего рядовое казачество выступало с требованиями не только о более частой нарезке общинных земель, но и о дополнительном распределения запасных станичных и войсковых земель. В результате сроки «земельных» переделов существенно сокращались; так, если в период с 1860 по 1870 гг. переделы проводились раз в 12 лет, то в конце XIX - начале XX вв. - уже раз в 9 лет [Ратушняк, 1996, с. 399]. Но даже более частые нарезки станичной земли не могли стабилизировать ситуацию с сокращением казачьего земельного надела. Так, по состоянию на 1896 г. в Кубанской области казачий земельный пай составлял в среднем 13,6 дес. земли, однако данные цифры не отражали реальной действительности на местах, где размер пая казаков отличался не только в разных отделах, но даже в станицах одного отдела. Так, в Прикубанских отделах (Черноморье) размер пая колебался от 7 до 22 десятин земли, а в Закубанских отделах - от 4 до 30 десятин [Ратушняк, 1974, с. 206].

Следует отметить, что на неравномерное распределение земельных паев влияла не только демографическая составляющая, но и Положение «О размежевании земель Кубанского казачьего войска» от 26 апреля 1869 г. По данному Положению, все казачьи станицы и хутора разбивались на пять категорий, в зависимости от которых происходило наделение земельными паями. Так, в первой категории полагалось по 16, во второй $-17,5$, в третьей - 21,5, в четвертой - 26, а в пятой - по 30 десятин земли [Ратушняк, 1974, c. 206], таким образом, именно данное положение было основой неравномерного распределения земельных паев в области.

Войсковое руководство было обеспокоенно сокращением казачьих наделов и постоянно выделяло значительные денежные средства на скупку частновладельческих земель. Так, в 1901 г. было выделено 100 тыс. руб., а в 1902 г. сумма была удвоена [Сименеко, 2003, с. 87]. Однако следует отметить, что, несмотря на постоянное уменьшение казачьих земельных паев, большинство казачьих семей имели по 2-3, а иногда и более паев. В среднем казачий семейный надел составлял по разным данным от 30 до 52 десятин земли [Куценко, 1993, с. 76-77].

Одним из катализаторов обострения земельного вопроса в Кубанской области была частновладельческая (казачья и жалованная) земля. Формирование данной категории собственников земли было официально положено 10 мая 1862 г. положением «О заселении западной части Кавказского хребта казаками и другими переселенцами из России», в основу которого вошёл рескрипт от 24 июня 1861 г. Данное положение предоставляло казакампереселенцам в Закубанье земельные наделы в частную собственность с правом по «окончании службы свободу исключаться из казачьего сословия и продавать землю иногородним лицам» [Хрестоматия по Истории Кубани, с. 130].

В результате в руках частновладельческих собственников в зависимости от военного и гражданского чина оказались как сравнительно небольшие участки - от 5 до 50 десятин земли, так и крупные - от 100 до 1500 [Остапенко, 2004, с. 63]. Как правило, большинство именно «пожалованных» земельных участков продавалось практически сразу, как только проводилось их межевание. Так, к 1886 г. было продано 24,5\% данных участков, а к началу ХX в. - уже больше половины [Ратушняк, 1974, с. 209]. Большая часть оставшихся участков поступало в залог банков. Так, за период с 1894-1896 гг. в Ейском и Темрюкском отелах в банках было заложено 616 имений общей площадью 184 тыс. десятин земли [Кубанские Областные ведомости, 1899]. Заложенные земли приносили их владельцам не только крупные кредиты, но и обязывали регулярно делать выплаты банкам. Неуплата долгов по кредитам приводила к неминуемой продаже банками земельных участков и имений. Так, только за 1898 г. Дворянский земельный банк и Донской земельный банк выставили на продажу 8,5 и 11,2 тыс. десятин земли [Ратушняк, 1996, с. 351]. 
Кубанское зажиточное казачество (офицерство и чиновники) всячески стремилось путем выполнения ряда законодательных формальностей перевести свои земли, которые им давались вместо пенсий, в прямую частную собственность. Как отмечал Ф.А. Щербина, «давнишние устремления чиновного казачества создать себе собственное, частное землевладение на войсковых землях осуществилось» [Остапенко, 2004, с. 64]. Однако дальнейшие попытки перевести в частную земельную собственность казачьи земли не находили поддержки ни со стороны рядового казачества, ни военного министерства. Основная опасность в легализации частного земледелия на Кубани была в том, что значительная часть рядового казачества (вследствие продаж земельных участков) могла перейти в категорию безземельного населения. Таким образом, к началу XX в. на Кубани хоть и была заложена категория частновладельческого земледелия, основная масса войсковой земли так и осталась в пользовании казачьего общества.

Рост численности населения области и массовая миграция крестьянского населения оказали существенное влияние не только на ускоренное развитие земледелия, но и, как следствие, на увеличивающийся спрос на покупку частновладельческой земли и аренду земли в станичных обществах.

Основными покупателями земли выступали представители именно не войскового сословия (купцы, мещане, крестьяне переселенцы, состоявшие в крестьянских товариществах и получавшие ссуды от Крестьянского поземельного банка). Так, купцы Петрик приобрели свыше 12 тыс. десятин земли, предприниматели овцеводы Николаенко и Мазаевы - по 30 и 8 тыс. десятин земли [Прошлое и настоящее Кубани..., 1994]. Однако таких крупных земельных владений было не так много, так как в связи с высокими ценами (вначале XX в. цены поднялись до 500-600 руб. за десятину пашни [Сименеко, 2003, с. 54]), и для получения максимальной прибыли от продажи и аренды земли шел процесс сознательного дробления земельных участков. Таким образом, купля продажа земли ввиду скудности частновладельческого фонда и постоянно растущих на неё цен не приобрела должных размеров.

Для переселенцев становилось гораздо выгоднее брать в аренду частную, государственную и казачью землю. Основной причиной, толкавшей казачьи семьи сдавать в аренду свои земельные паи, было отсутствие земледельческих орудий, долги и банальное желание получить деньги без существенных затрат. Именно данные обстоятельства привели к массовой сдаче в аренду казачьих паёв. Посетивший область начальник Главного управления казачьих войск генерал-лейтенант П.О. Щербов-Нефедович писал: «Значительная часть паевой земли не обрабатывается самими владельцами паев, а сдается ими в аренду иногородним или своим же, более состоятельным казакам одностаничникам» $[\mathrm{Pa-}$ тушняк, 1996, с. 356]. Статистик Министерства земледелия и государственных имуществ В.Е. Постников так описывал ситуацию с земельной арендой в области: «Надельная земля служит в настоящее время предметом обширной спекуляции, под землю получают займы с выдачей векселей, земля сдается и продается на год, два и более долгие сроки» [Куценко, 1993, с. 74].

Так как основными арендаторами выступали иногородние, возникавшие земельные споры и конфликты приводили к неизбежному столкновению интересов данных сословий. Как пишет Ф.А. Щербина, с увеличением населения обнаружились «стеснения в землепользовании» [История Кубани, с. 160]. Также существенный негатив у многих представителей казачества вызывало то обстоятельство, что казаки, отягощенные воинской повинностью, уступали более предприимчивой части иногородних в ведении земледелия и торговли.

Именно данные факторы способствовали появлению среди основной массы казачества тенденции на еще большее ограничение прав иногородних. Областное руководство, обеспокоенное ростом обнищания рядового казачества, вызванного масштабной и бесконтрольной арендой общинной земли, винило во всех бедах переселенцев «иногородних». 
В результате был принят ряд постановлений, которые были направлены как на снижение притока переселенцев, так и на ограничение хозяйственной деятельности уже проживавших в области иногородних жителей.

Так, 13 мая 1883 г. было внесено изменение в закон «О дозволении русским подданным невойскового сословия селиться и приобретать собственность в землях казачьих войск» от 29 апреля 1868 г. Данное изменение ограничивало возможность приобретения недвижимости иногородними в области, оставляя этот вопрос на усмотрение кавказского начальства. В отношении хозяйственной деятельности иногородним запрещалось выпасать на станичных выгонах более четырех голов крупного и шести голов мелкого скота на одно хозяйство. Те, у кого было больше скота, были обязаны вносить взносы, а несение натуральных повинностей, которое возлагалось на всех жителей станицы, со временем было переложено на иногородних жителей. Ограничения коснулись и жизни детей иногородних, которым разрешалось ходить в школу только во вторую очередь и только после приема детей казаков [Ладоха, 1923, с. 20].

Таким образом, существенные изменения, коснувшиеся жизни иногороднего населения, привели к сокращению притока переселенцев в область. Так, если в 1869-1889 гг. среднегодовой прирост иногороднего населения области составлял 35,6 \%, то в период 1889-1904 гг. показатели прироста снизились до 3,5 \% [Кудинова, 2003, с. 71].

Разработанные постановления коснулись и казачьего землепользования, чтобы прекратить самовольное дробление земельных наделов и уменьшить сроки аренды. Было внесено изменение в закон «О поземельном устройстве в казачьих войсках» от 21 апреля 1869 г., касавшееся договоров на аренду земельных наделов и пастбищ - договоры должны были заключаться на срок не более одного года. Уменьшение арендных сроков должно было урегулировать постоянно меняющиеся цены, а также предотвратить фактическую потерю казаками земельных наделов от долгосрочной аренды. Данное изменение вступило в силу 3 июня 1891 г. [Сименеко, 2003, с. 79].

Но уменьшение сроков аренды отрицательно сказалось на ведении сельского хозяйства на войсковых землях, так как препятствовало рациональному использованию арендуемых участков и давало больше преимуществ частновладельческим и казенным землям, где сроки аренды были значительно выше. Постоянный рост цен на аренду земли (следует отметить, что значительное влияние на рост цен на аренду земли оказал «хлебный бум» 1892, 1893 гг., когда после неурожая и голода 1891 г. во многих губерниях цены на зерно и аренду земли подскочили в несколько раз) сделал невыгодном заключение краткосрочных и долголетних договоров (основная часть договоров на аренду заключалось в основном от 3 до 6 лет). В итоге в 1912 г. краткосрочная аренда была отменена. Казакам разрешалось сдавать в аренду земельные участки сроком до 6 лет [Ратушняк, 1996, c. 401$]$.

Отрицательной стороной аренды наравне с ростом цен была и так называемая «субаренда». Данный вид аренды был важнейшим инструментом в получении максимальной прибыли зажиточными казаками и крестьянами. Именно субаренда сказывалась на положении беднейших слоев населения и приводила к еще большему социальному обострению в регионе. Крупные предприниматели переселенцы, занимавшиеся скотоводством, арендовали большие участки (до 20 т. десятин) казенных земель на долголетнею аренду по минимальной цене (так, цены за 1 десятину казенной земли в области составляли 28 коп.) и отдавали ее в субаренду уже по цене 1-2 руб. за десятину [Ратушняк, 1996, c. 354-355].

Таким образом, бесконтрольная аренда, субаренда и покупка частновладельческой земли была не только одним из главных способов обогащения для зажиточного казачества, но и основным фактором, влиявшим на социальное расслоение кубанского казачества. В результате аренды казаки сами оказались стесненными в пользовании общественными выгонами и пастбищами, а сдавшие в аренду земельные паи казаки сами попадали в 
кабалу и вынуждены были вскоре сами наниматься на работу к своим арендаторам. Так, по данным Л.В. Македонова, в конце XIX в. батраков давали 6637 казачьих семей, составлявших 5,2 \% казачьего населения. Причем большей частью батраками были женщины. Это объяснялось тем, что мужчины были заняты на военной службе [Куценко, 1993, c. 81]. Наиболее бедными в Кубанской области были Закубанские станицы. Так, по данным статистического исследования, из 131 станицы Нагорной полосы было выявлено, что бедными и малоимущими было от 36,9 до 43,5 \% хозяйств; по данным атаманов из 218 станиц и хуторов, показатель бедных хозяйств составил около 48 \% [Куценко, 1993, c. 87].

Существенное влияние на обеднение рядового казачества оказали неурожаи 1880 , 1891, 1897 гг., когда многие казачьи семьи лишились паёв из-за долгов и «зерновых ссуд». Данные неурожаи только усиливали социальное расслоение среди станичного казачества.

Следует отметить, что в среднем на одно бедняцкое казачье хозяйство приходилось по 1-2 лошади, пара быков или одна корова. Однако именно количество лошадей являлось основным показателем социально-экономического расслоения казачьих хозяйств.

Так, Л.И. Футорянский в своей работе «Расслоение казачьих хозяйств в конце XIX - начале XX вв.» приводит данные, что на 1912 г. в Кубанской области из 183088 хозяйств безлошадных было 40074 (21,9 \%), а однолошадных - 15972 (8,6 \%), соответственно, бедных хозяйств было $30,5 \%$, середняцких (наличие двух и трех лошадей) и богатых хозяйств (четыре и более лошади) было примерно равное число - $62901(34,3)$ и 64141 $(35,2)$ соответственно [Футорянский, 1974, с. 304]. Таким образом, Л.Н. Футорянский делил кубанское казачество на практически равные социальные группы.

Войсковая администрация всячески старалась поддерживать рядовое казачество, казакам выдавались ссуды под будущий урожай из войсковых или станичных касс под небольшой процент или беспроцентные. Однако большая часть долгов так и оставалась не погашенной. По данным за 1899 г., казаки были должны в Войсковую казну 950000 руб. ${ }^{30}$ За долги у казаков забирали половину, а иногда и весь земельный надел, который за счет сдачи в аренду компенсировал долг владельца. Каждый год в областной газете приводились данные о количестве изъятой у казаков за долги земли. Так, в 1895 г. у казаков было изъято 29953 тыс. десятин земли, а уже в 1898 г. - 55819 тыс. десятин [Прошлое и настоящее Кубани..., 1994, с. 160].

Казачьи земли не облагались денежными податями, а заменялись военной повинностью, которую несли казаки практически всю жизнь и которая становилась для них труднейшей заботой. Именно воинская повинность была одним из основных факторов ухудшения материального положения казаков. Снаряжение на службу, особенно для рядовых казаков, было тяжелым бременем. Так, если в середине XIX в. стоимость снаряжения и строевой лошади не превышала 72 руб., то с включением казачьих частей в состав кавалерийских дивизий в 1875 г. средняя стоимость снаряжения уже составила около 180 руб. [Остапенко, 2004, с. 73]. К концу XIX в. экипировка одного конного казака обходилась примерно 274 руб., а в начале ХХ в. стоимость выросла до 320 руб.

При снаряжении на службу основные траты казака приходились на покупку строевой лошади. Поэтому в начале XX в. стали появляться случаи прихода казаков и даже групп казаков на сборные пункты без лошадей. Так, в «Областных ведомостях» за 1896 г. отмечалось: «станица Попутная - 16 казаков явилось на сборы без лошадей, станица Белореченская - из 15 лошадей своих ни одной, все наняты по 6 руб. в месяц, станица Бжедуховская - своя лошадь только у одного казака, остальные наняты ко дню смотра по 50 коп. в день» [Кубанские областные ведомости, 1896]. Таким образом, для многих казаков стало выгодно приходить на сборы без лошади, объясняя это отсутствием денег, или брать строевого коня в аренду. Атаманы наказывали рядовых казаков взысканиями, аре-

${ }^{30}$ ГАКК. Ф. 454. Оп 2. Д. 1229. Л. 34-35. 
стами, были даже случаи разжалования, но данные меры уже не могли изменить ситуацию.

Многие казаки, не имея возможности купить строевого коня, зачислялись в менее почетные пешие подразделения. Так, например, снаряжение пешего казака в 1898 г. обходилось в 109 руб. [История Кубани, с. 144]. Для урегулирования проблемы со снаряжением казаков каждый год из войсковых и станичных средств выделялись деньги на снаряжение и покупку строевых лошадей для бедных казаков. Так, если в 1907 г. была выделена 281 тыс. руб. [Отчет начальника Кубанской области за 1907], то в 1912 г. было израсходовано 456 тыс. руб. [Куценко, 1993, с. 86].

Государство также выдавало выходящим на службу казакам (для покупки снаряжения и его починки) единоразовое материальное пособие. Однако данные выплаты были незначительными и покрывали лишь небольшую часть расходов. Таким образом, проблемы со снаряжением доводили казаков до крайности. Так, иногда отцы казаков, отправляемых на службу, просили станичное правление взять в свое распоряжение земельные паи их сыновей и тем самым снять с себя заботу о снаряжении их на службу. Журнал «Голос казачества» в начале XX в. отмечал, что «крестьяне с данной проблемой (снаряжением) не сталкиваются, у крестьянина чем больше сыновей, тем он богаче, а для казака дело обстояло совсем наоборот» [Остапенко, 2003, с. 73-74].

Недовольство казаков вызывал и тот факт, что воинская повинность ограничивала также и свободу передвижения. Так, на основании принятых в 1897 г. Правил «Об увольнении в мирное время казаков служилого состава» казак не мог отлучаться из станицы или хутора больше чем на 3 месяца, и то только с разрешения станичного руководства. Отсрочка до года предоставлялась только при одобрении атамана и всего станичного общества, но с обязательным отбыванием летних и зимних лагерных сборов. Покидать место жительства казакам строевого разряда строго запрещалось, т. е. казак не мог быть принят ни на какую другую службу или работу.

\section{Заключение}

Таким образом, на социальное расслоение казачества и формирование категории беднейшего казачества оказывали существенное влияние такие факторы, как стремительное развитие экономики с её процессами капитализации земельных отношений, долголетняя воинская обязанность, сословная замкнутость, а также нерациональное использование земельных паёв. Данные факты ставили казачье хозяйство в крайне тяжелое финансовое положение, а если учесть, что основным богатством бедных казаков была земля, то снаряжение на службу для них становилось слишком тяжелым бременем, для выполнения которого они вынуждены были сдавать свои земельные наделы в аренду, переходя, таким образом, в разряд безземельного или малоземельного казачества. Именно формирование данной категории казачества в совокупности с наличием в области безземельного иногороднего населения привело не только к обострению земельного вопроса в начале XX в., но и к тому, что именно данные социально-сословные группы стали наиболее революционно настроенной частью населения области, заинтересованной только в радикальном решении земельных и социальных проблем.

\section{Список литературы}

1. История Кубани. 2015. Под общ. ред. проф. В.В. Касьянова. Краснодар, Периодика Кубани, 352.

2. Кубанские областные ведомости. Екатеринодар. 1896. 30 апреля.

3. Кубанские областные ведомости. Екатеринодар. 1899. 7 ноября.

4. Кудинова А.В. 2003. Кубанская область и Черноморская губерния в период первой российской революции 1905-1907 гг.: дис. канд. ист. наук. Краснодар. 212. 
5. Куценко И.Я. 1993. Кубанское казачество. Краснодар, Краснодарское книжное издательство, 583.

6. Ладоха Г.В. 1923. Очерки Гражданской войны на Кубани. Краснодар, Кооперативное издательство «Буревестник», 122.

7. Остапенко П.И. 2004. Казачьи государственные образования на юге России (февраль 1917 - начало 1920 г.) Историко-правовой анализ: дис. док. юрид. наук. Краснодар. 443.

8. Отчет начальника Кубанской области за 1901.

9. Отчет начальника Кубанской области за 1907.

10. Первая всеобщая перепись населения Российской империи 1897. Т. 65. Кубанская область. Санкт-Петербург, 1905. 263.

11. Прошлое и настоящее Кубани в курсе отечественной истории. Часть 1. 1994. Под. ред. проф. В.Н. Ратушняка. Краснодар, Советская Кубань, 272.

12. Ратушняк В.Н. 1996. Очерки Истории Кубани с древнейших времен по 1920 г. Краснодар, Советская Кубань. 654.

13. Ратушняк В.Н. Земельный фонд Кубанской области и его распределение в период капитализма. 1974. Ежегодник по аграрной истории Восточной Европы. Вильнюс, Минтис: $205-214$.

14. Симененко Л.В. 2003.Основные направления земельной политики на Кубани в конце XVIII - начале XX века: дис. канд. ист. наук. Ростов-на-Дону. 268.

15. Трехбратов Б.А. 2003 Истрия Кубани с древнейших времен до начала $\mathrm{XX}$ века. Краснодар, Кубанское книжное издательство. 440.

16. Футорянский Л.И. 1974. Расслоение казачьих хозяйств в конце XIX - начале XX в. Ежегодник по аграрной истории Восточной Европы. Вильнюс, Минтис: 292-306.

17. Хрестоматия по Истории Кубани. 2015. Под общ. ред. проф. В.В. Касьянова. Краснодар, Периодика Кубани. 400.

\section{References}

1. Istoriya Kubani [History of the Kuban]. 2015. Pod obshch. red. prof. V.V. Kas'yanova. Krasnodar, Periodika Kubani, 352.

2. Kubanskie oblastnye vedomosti [Kuban Regional news]. Ekaterinodar. 1896. 30 aprelya.

3. Kubanskie oblastnye vedomosti [Kuban Regional news]. Ekaterinodar. 1899. 7 noyabrya.

4. Kudinova A.V. 2003. Kubanskaya oblast' i Chernomorskaya guberniya v period pervoy rossiyskoy revolyutsii 1905-1907 gg. [Kuban region and the Black Sea province during the first Russian Revolution of 1905-1907]: dis. kand. ist. nauk. Krasnodar. 212.

5. Kutsenko I.Ya. 1993. Kubanskoe kazachestvo [Kuban Cossacks]. Krasnodar, Krasnodarskoe knizhnoe izdatel'stvo, 583.

6. Ladokha G.V. 1923. Ocherki Grazhdanskoy voyny na Kubani [Essays on the Civil War in the Kuban]. Krasnodar, Kooperativnoe izdatel'stvo «Burevestnik», 122.

7. Ostapenko P.I. 2004. Kazach'i gosudarstvennye obrazovaniya na yuge Rossii (fevral'1917 nachalo 1920 g.) Istoriko-pravovoy analiz [Cossack state formations in the South of Russia (February 1917 - early 1920) Historical and legal analysis]: dis. dok. yurid. nauk. Krasnodar. 443. 1901].

8. Otchet nachal'nika Kubanskoy oblasti za 1901 [Report of the head of the Kuban region for

9. Otchet nachal'nika Kubanskoy oblasti za 1907 [Report of the head of the Kuban region for 1907].

10. Pervaya vseobshchaya perepis' naseleniya Rossiyskoy imperii. 1897. T. 65. Kubanskaya oblast' [The first general census of the population of the Russian Empire in 1897. Kuban region]. SanktPeterburg, 1905. 263.

11. Proshloe i nastoyashchee Kubani v kurse otechestvennoy istorii. Chast' 1 [The past and present of Kuban in the course of National history. Part 1]. 1994. Pod. red. prof. V.N. Ratushnyaka. Krasnodar, Sovetskaya Kuban', 272.

12. Ratushnyak V.N. 1996. Ocherki Istorii Kubani s drevneyshikh vremen po 1920 g. [Essays on the History of the Kuban from ancient times to 1920]. Krasnodar, Sovetskaya Kuban'. 654.

13. Ratushnyak V.N. Zemel'nyy fond Kubanskoy oblasti i ego raspredelenie v period kapitalizma [Land fund of the Kuban region and its distribution in the period of capitalism]. 1974. 
Ezhegodnik po agrarnoy istorii Vostochnoy Evropy [Yearbook on the Agrarian History of Eastern Europe]. Vil'nyus, Mintis: 205-214.

14. Simenenko L.V. 2003.Osnovnye napravleniya zemel'noy politiki na Kubani v kontse XVIII - nachale XX veka [The main directions of land policy in the Kuban in the late XVIII - early XX century]: dis. kand. ist. nauk. Rostov-na-Donu. 268.

15. Trekhbratov B.A. 2003 Istriya Kubani s drevneyshikh vremen do nachala XX veka [Istria of the Kuban from ancient times to the beginning of the XX century]. Krasnodar, Kubanskoe knizhnoe izdatel'stvo. 440.

16. Futoryanskiy L.I. 1974. Rassloenie kazach'ikh khozyaystv v kontse XIX - nachale XX v. [Stratification of Cossack farms at the end of the XIX - beginning of the XX century]. Ezhegodnik po agrarnoy istorii Vostochnoy Evropy [Yearbook on the Agrarian History of Eastern Europe]. Vil'nyus, Mintis: $292-306$.

17. Khrestomatiya po Istorii Kubani [Textbook on the History of the Kuban]. 2015. Pod obshch. red. prof. V.V. Kas'yanova. Krasnodar, Periodika Kubani. 400.

\section{ИНФОРМАЦИЯ ОБ АВТОРЕ}

Пахомов Андрей Вячеславович, аспирант кафедры истории, философии и психологии, преподаватель кафедры Физического воспитания и спорта Кубанского государственного технологического университета, г. Краснодар, Россия

\section{INFORMATION ABOUT THE AUTHOR}

Andrey V. Pakhomov, post-graduate student of the Department of History, Philosophy and Psychology, Lecturer of the Department of Physical Education and Sports, Kuban State Technological University, Krasnodar, Russia 